\title{
ALTERATIONS OF COPY NUMBER OF METHYLATION PATTERN IN MISMATCH REPAIR GENES BY METHYLATION SPECIFIC-MULTIPLEX LIGATION-DEPENDENT PROBE AMPLIFICATION IN CASES OF COLON CANCER
}

\author{
Onrat $\mathrm{ST}^{1^{*}}$, Çeken $\mathrm{I}^{2}$, Ellidokuz E ${ }^{3}$, Kupelioğlu A ${ }^{4}$
}

\begin{abstract}
*Corresponding Author: Serap Tutgun Onrat, Department of Medical Genetics, Afyon Kocatepe University Medical Faculty, ANS Arastırma Uygulama Hastanesi, Morfoloji Binası, Ozdilek yolu, Afyonkarahisar, 03200, Turkey; Tel.: +90-272-246-3301, Fax:+90-272-246-3300, E-mail: tutgunonrat@ yahoo.com, sonrat@aku.edu.tr
\end{abstract}

\begin{abstract}
Genetic alterations and changes in genomic DNA cytosine methylation patterns are associated with all types of cancer and are caused by germline mutations in DNA mismatch repair (MMR) genes, predominantly MLH1 (MutL homolog 1, 19 exons) and MSH2 (MutS homolog 2, 16 exons). Genomic DNA was extracted from tissue samples embedded in paraffin from 49 patients with adenocarcinoma and from 21 patients with carcinoma for the study group; genomic DNA was extracted from lymphocytes from 10 healthy donors for the control group. We used methylation specific multiplex ligation-dependent probe amplification (MS-ML$\mathrm{PA}$ ), which allows the detection of copy number changes and unusual methylation levels of 10 to 50 different sequences in one reaction by use of the methylationsensitive restriction enzyme $H h a$ I and sequence-specific capillary electrophoresis for the study of 24 genes.

We found the mean methylation rates for MLH1 (97.14\%), MSH2 (24.28\%), MSH6 (MutS homolog 6) (67.14\%), MSH3 (MutS homolog 3) (78.57\%), MLH3 (MutL homolog 3) (75.71\%), PMS2 (postmeiotic seg-

The Supplementary Material referred to in this article can be accessed at http://www.bjmg.edu.mk/record.asp?recordid=588

1 Department of Medical Genetics, Afyon Kocatepe University of Medical Faculty, Afyonkarahisar, Turkey

2 Department of Molecular Biology, Afyon Kocatepe University of Science Faculty, Afyonkarahisar, Turkey

3 Department of Internal Medicine and Gastroenterology, Celal Bayar University of Medicine Medical Faculty, Manisa, Turkey

4 Güneş Pathology Laboratory, Alsancak, Izmir, Turkey
\end{abstract}

regation increased 2) (65.71\%), MGMT(O-6-methylguanine-DNA methyltransferase) (82.85\%). We conclude that the mismatch repair (MMR) system is critical for the maintenance of genomic stability.

Key words: Colon cancer, Methylation specificmultiplex ligation-dependent probe amplification (MSMLPA), Mismatched repair (MMR) Genes, Methylation, Copy number

\section{INTRODUCTION}

At least six different mismatch repair (MMR) genes [MLH1 (MutL homolog 1, 19 exons), MSH2 (MutS homolog 2, 16 exons), MSH6 (MutS homolog ๑), MLH3 (MutL homolog 3), PMS2 (postmeiotic segregation increased 2) and MSH3 (MutS homolog 3)] have been identifed. Their protein products interact to form protein complexes that mediate distinct functions in the repair of insertion/deletion and single-base substitution mismatches [1]. The product of MLH1 and PMS2 direct the mismatch recognition complex to repair insertion/deletion loops (IDLs), whereas those of MSH2, MSH6 are directed to single-base mismatches [1-3]. The mismatch repair (MMR) system is critical for the maintenance of genomic stability and increase the fidelity of DNA replication by identifying and excising single-base mismatches and IDLs that may arise during DNA replication. Cells that have MMR deficiency may lead to the accumulation of mutations that initiate cancer. The MMR genes are involved in one of the most prevalent cancer syndromes in humans known 
as hereditary non polyposis colon cancer (HNPCC). Mutations in MLH1 and MSH2 have been found in about $90 \%$ of HNPCC cases. Mutations in other MMR genes have been less frequent in HNPCC patients. In many sporadic colon cancers, hypermethylation of the MLH1 gene promoter that results in silencing of its transcription has been observed more frequently than mutations [4].

DNA MMR is an evolutionarily conserved postreplicative repair mechanism, which eliminates mistakes in the newly synthesized DNA strand during DNA replication [5]. Such biosynthetic mistakes include base/base mismatches and IDLs. The latter mistakes arise during the slippage of the primer against the template strand, especially in repeated sequence motifs like microsatellites. A model for the eukaryotic MMR mechanism is provided by Saccharomyces cerevisiae [6] where mutations in three genes lead to 100- to 700 -fold increases in mutation levels at poly (GT) sequences. The discovery of defects in MMR that co-segregate with certain cancer predisposition syndromes (for example, HNPCC) highlights the essential role of MMR in mutation avoidance. Mismatch repair consists of five major steps: 1) mismatch recognition, 2) assembly of the repair complex, 3) strand discrimination, 4) degradation of the mismatch-containing strand, and 5) resynthesis of the excised strand [5]. Depending on the type of mismatch on the newly synthesized DNA strand, either an MSH2-MSH6 (MutS $\alpha$ ) or MSH2-MSH3 (MutS $\beta$ ) dimer recognizes the mismatch. The MSH2-MSH6 complex is involved in the repair of single base pair mismatches, whereas the MSH2-MSH3 complex preferentially targets mismatches from two up to 13 nucleotides [7]. The first HNPCC-associated DNA MMR gene, MSH2, was identified by genetic linkage analysis [8]. To date, six human MutS homologues and four MutL homologues are known to participate in DNA MMR, but not all are associated with HNPCC predisposition [9]. According to recent knowledge, HNPCC predisposition is a consequence of an inherited mutation in one of four MMR genes (MLH1, MSH2, MSH6 and PMS2) resulting in defective DNA MMR. The roles of MLH3, MSH3 and PMS1 in HNPCC predisposition is less clear [1012]. Estimates of the relative proportions of mutations in the different MMR genes vary depending on the country and population [13-16]. DNA changes are crucial steps in tumor initiation and progression [17]. Next to mutations in oncogenes and tumor suppres- sor genes, alterations in DNA copy numbers and DNA methylation patterns have been observed as common changes in colorectal and gastric cancer. Copy number changes can lead to increased or decreased gene expression, whereas mutations can have an activating or inactivating effect. Besides these genetic changes, epigenetic changes, such as DNA methylation, may result in altered gene expression levels. Usually, aberrant methylation of normally unmethylated $\mathrm{CpG}$-rich areas, also known as $\mathrm{CpG}$ islands, which are located in the promoter regions of genes, have been associated with transcriptional inactivation of important tumor suppressor genes, DNA repair genes or metastasis inhibitor genes $[18,19]$.

\section{MATERIALS AND METHODS}

Patients and Clinical Data. For this study, samples were retrieved from the Güneş Pathology Laboratory at Alsancak, Izmir, Turkey. Colorectal cancer tissue samples embedded in paraffin were used in our study. Seventy patients comprised our study population, 41 males $(58.6 \%)$ and 29 females $(41.4 \%)$. The mean age of the males was $55.02 \pm 2.39$ and $61.76 \pm$ 12.58 for the females, $(p=0.029,<0.05)$. According to the age groups, $60<38(54.3 \%)$ and $60>32(45.7 \%)$ patients suffered with colorectal cancer. Of the 70 colorectal cancer specimens tested, the mean age of patients with adenocarsinomas was $61.63 \pm 11.45$ and those with carcinomas was $48.91 \pm 11.57$. Adenocarcinoma was found in $49(70.0 \%)$ and adenoma in 21 (30.0\%) of the total 70 colorectal cancer speciments.

Paraffin-Embedded DNA Extraction. Slides with a slice of paraffin-embedded tissue $(5 \times 5 \mathrm{~mm}$, $10 \mathrm{~mm}$ thick) were heated for $30 \mathrm{~min}$. at $70^{\circ} \mathrm{C}$ to melt the paraffin and then placed in fresh Xylol for 5 min. until the paraffin oil was completely dissolved. The slides were then kept for 30 seconds each in 99.96 and $75 \%$ ethanol and tap water, and finally placed in $1 \mathrm{M}$ $\mathrm{NaSCN}$ at $37^{\circ} \mathrm{C}$ overnight. They were then washed with TE buffer [10 mM Tris- $\mathrm{HCl}(\mathrm{pH} 8.5)$ and $1 \mathrm{mM}$ EDTA] and air dried; $20-40 \mu \mathrm{L}$ of Proteinase K solution $[2 \mathrm{mg} / \mathrm{ml}$ recombinant Proteinase K (Roche Diagnostic, Mannheim, Germany) in $25 \mathrm{mM}$ Tris- $\mathrm{HCl}(\mathrm{pH}$ 8.2)] were then applied to the tissue, which was then transferred to a $1.5 \mathrm{~mL}$ tube containing $100 \mathrm{~mL}$ Proteinase $\mathrm{K}$ solution and incubated overnight at $37^{\circ} \mathrm{C}$. After in incubation at $80^{\circ} \mathrm{C}$ for $20 \mathrm{~min}$., the tubes were centrifuged for $10 \mathrm{~min}$. at 13,000 rpm on an Eppendorf 
microcentrifuge. Finally, $2 \mathrm{~mL}$ of the supernatant was used for each methylation specific-multiplex ligationdependent probe amplification (MS-MLPA) reaction.

\section{METHYLATION SPECIFIC-MULTI PLEX LIGATION-DEPENDENT PROBE AMPLIFICATION ASSAY}

Methylation Analysis. The MS-MLPA for methylation status in tumor DNA of MLH1, MSH2, MSH6 promoter regions used the SALSA ME011 kit and protocols provided by the manufacturer (MRC-Holland, Amsterdam, The Netherlands). This ME011-A1 MMR probe mix was developed to detect aberrant $\mathrm{CpG}$ islands methylation of six MMR genes and includes five probes for MLH1, three probes MSH2, three probes for MHSH6, three probes for MSH3, one probe for MLH3, three probes for PMS2 and three probes specific for the MGMT promoter region. The MGMT promoter plays a role in removing $\mathrm{O}(6)$-alkylguanine, which is the major mutagenic and carcinogenic lesion induced by alkylating mutagens. The MLH1 gene is located at chromosome 3p22.1, MLH3 at chromosome $14 \mathrm{q} 24.3, \mathrm{MSH} 2$ at 2p21, MSH3 at 05q14.1, MSH6 gene at 2p16, PMS2 at 7p22 and the MGMT gene is located at chromosome 10q26. The kit includes five probe pairs for MLH1 (with the respective HhaI sites located at $-638,-402,-251 /-245,-8$ and +220 relative to the initiating ATG; GenBank accession number U26559), three probe pairs for MSH2 (HhaI positions at $-264,-200$ and $+133 /+148$ relative to ATG; GenBank accession number AB006445) and three probe pairs for MSH6 (HhaI positions at $-293,-100 /-143$ and -64 relative to ATG; Gen Bank accession number U73732). Normal DNA specimens derived from lymphocytes from healthy controls were included in every assay. For each MLPA reaction, $150 \mathrm{ng}$ of DNA was used.

Approximately $25 \mathrm{ng}$ of genomic DNA in $5 \mu \mathrm{L}$ of TE buffer [10 mM Tris- $\mathrm{HCl}(\mathrm{pH} 8.5)$ and $1 \mathrm{mM}$ EDTA] was denatured for $10 \mathrm{~min}$. at $98^{\circ} \mathrm{C}$. The SALSA MLPA buffer $(1.5 \mathrm{~mL})$ and MS-MLPA probes (1 fmol each and $1.5 \mu \mathrm{L}$ vol) were then added, and after incubation for $1 \mathrm{~min}$. at $95^{\circ} \mathrm{C}$, were allowed to hybridize to their respective targets for 16 hours at $60^{\circ} \mathrm{C}$. The mixture was then diluted at room temperature with $\mathrm{H}_{2} \mathrm{O}$ and $3 \mu \mathrm{L}$ Ligase buffer A to a final volume of 20 $\mu \mathrm{L}$ and divided equally into two tubes. While at $49^{\circ} \mathrm{C}$, a mixture of $0.25 \mu \mathrm{L}$ Ligase-65 (MRC-Holland), $5 \mathrm{U}$
HhaI (Vavantis Technologies, Subang Jaya, Malaysia) and $1.5 \mu \mathrm{L}$ Ligase buffer B in a total volume of $10 \mu \mathrm{L}$ was added to one tube. For the second tube, the HhaI was replaced by $\mathrm{H}_{2} \mathrm{O}$. Simultaneous ligation and digestion was performed for $30 \mathrm{~min}$. at $49^{\circ} \mathrm{C}$, followed by $5 \mathrm{~min}$. at $98^{\circ} \mathrm{C}$. The ligation products were polymerase chain reaction (PCR)-amplified by addition of $5 \mu \mathrm{L}$ of this ligation mixture to $20 \mu \mathrm{L}$ PCR mixture containing PCR buffer, dNTPs, SALSA polymerase and PCR primers (one unlabeled and one D4-labeled) at $60^{\circ} \mathrm{C}$ as described by Schouten et al. [20]. The obtained PCR products were separated by capillary gel electrophoresis in an ABI 310 Genetic Analyzer Capillary, (Applied Biosystems, Foster City, CA, USA), and analyzed using GeneMapper ID V1.8 Software (Applied Biosystems). Information on both methylation status (10-100\% methylated) and copy number (number of methylated alleles) was obtained by comparing results of undigested and HhaI-digested samples using the Coffalyser V9.4 Software (MRC-Holland, http:// www.mrc-holland. com/) [21]. All analyses were performed in duplicate.

Methylation Specific-Multiplex Ligation-Dependent Probe Amplification Data Processing. Data analysis was performed in Excel as described by the manufacturer of the MLPA kits (MRC-Holland) [21]. To compensate for differences in PCR efficiency of the individual samples, the fraction of each peak is calculated by dividing the peak value of each probe amplification product by the combined value of the control probes within the sample. For hypermethylation analysis, this 'relative peak value' or so-called 'probe fraction' of the digested sample is divided by the 'relative peak value' of the corresponding undigested sample generating the 'methylation ratio'. From our dilution experiments, it became clear that the ratio indicates the percentage of methylated sequences. Duplicate experiments were performed for methylation analysis and average ratios were calculated. Copy number analysis can be performed using the MLPA results of the undigested samples. After calculation of the 'relative peak value' or so-called 'probe fraction', this is divided by the 'mean probe fraction' of this fragment within the included reference DNAs, generating the 'normalized peak value' or the so-called 'copy number ratio'. According to the Jeuken et al. [22] MLPA, thresholds to detect gains and losses were set at 1.2 and 0.8 , respectively.

Methylation dosage ratio was obtained from the following calculation: $\mathrm{Dm}=(\mathrm{Px} / \mathrm{Pctrl}) \mathrm{Dig} /(\mathrm{Px} / \mathrm{Pctrl})$ 


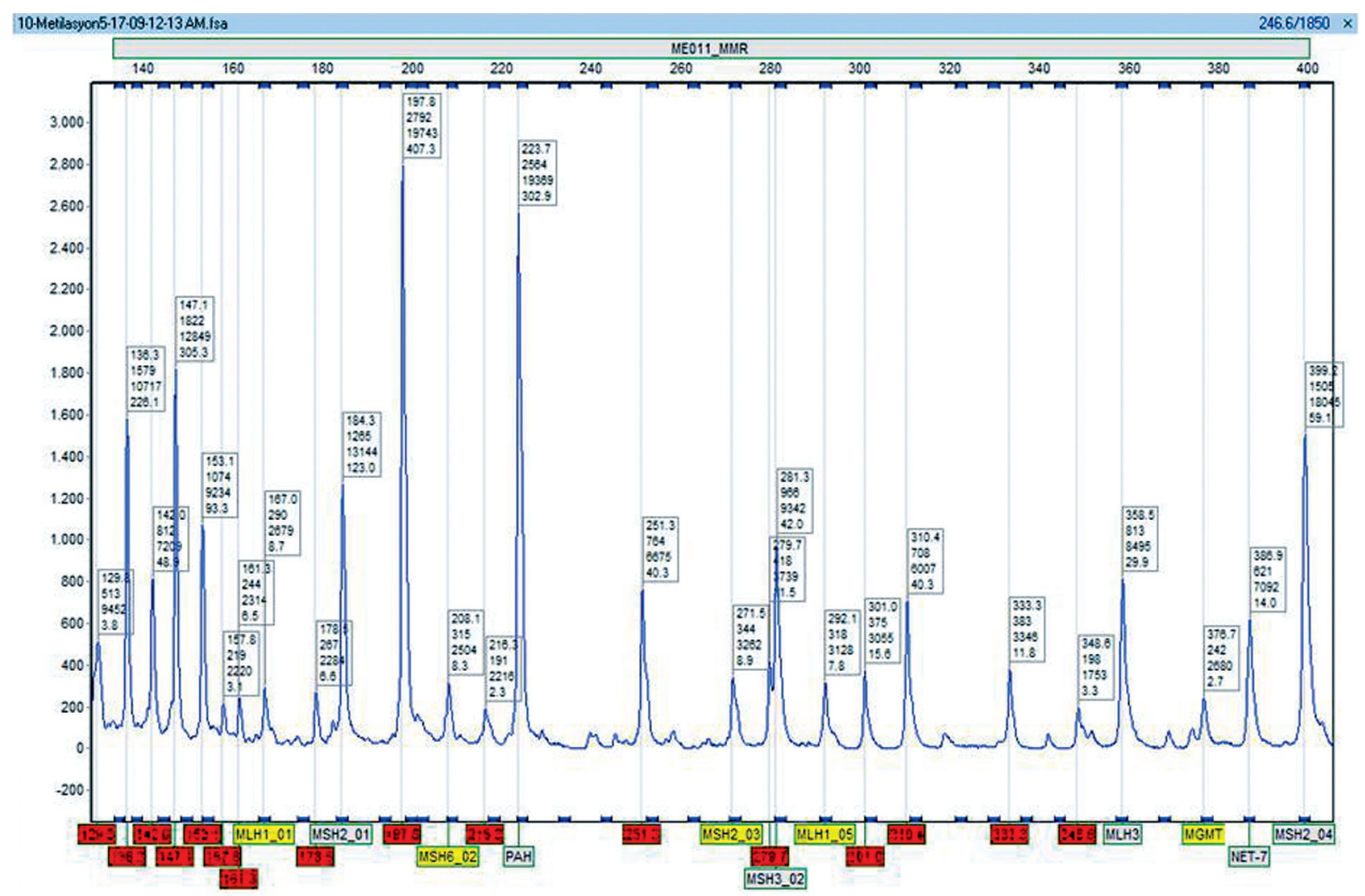

Figure 1. Methylation peaks belong to the MMR genes in colon cancer cases.

Undig, where Dm is the methylation dosage ratio, Px is the peak area of a given probe, Pctrl is the sum of the peak areas of all control probes, Dig stands for HhaIdigested samples, and Undig stands for undigested samples. A dosage ratio of 0.15 or higher, corresponding to $15 \%$ of methylated DNA, was interpreted to indicate promoter methylation [23].

Statistical Methods. All data were recorded by using a standard data form and analyzed by using SPSS 17.0 (SPSS, Inc., Chicago, IL, USA). Quantitative values were compared by using the Student $t$-test for independent groups, and for categorical data, $\chi 2$ and Student $t$ tests were applied. All $p$ values of less than $0.05(p=0.05)$ were considered to indicate statistical significance.

\section{RESULTS}

The methylation status of MS-MLPA probes is calculated by dividing: $a$ ) the intra-normalized ratio of each MS-MLPA probe obtained on the digested sample with $\boldsymbol{b})$ the intra-normalized ratio of each MS-

Table 1. Gender, age and diagnosis according to the distribution of the data.

\begin{tabular}{|l|c|c|c|c|c|c|}
\hline Parameters & $\mathbf{n}$ & $\mathbf{\%}$ & Mean & SS & $\begin{array}{c}\text { Student } \\
\text { t-Test }\end{array}$ & p Value \\
\hline Gender: male & 41 & 58.60 & 55.02 & 12.39 & & \\
\hline Gender: female & 29 & 41.40 & 61.76 & 12.58 & -2.33 & 0.029 \\
\hline Age: $<60$ years & 38 & 54.30 & 48.16 & 7.85 & & \\
\hline Age: $>60$ years & 32 & 45.70 & 69.28 & 6.51 & -12.12 & 0.000 \\
\hline Diagnosis: adenocarcinomas & 49 & 70.00 & 61.63 & 11.45 & & \\
\hline Diagnosis: adenoma & 21 & 30.00 & 48.91 & 11.56 & 4.25 & 0.000 \\
\hline
\end{tabular}


Table 2. Genes in the control and study groups as a threshold value determined according to the average methylation rates.

\begin{tabular}{|l|c|c|}
\hline Gene & $\begin{array}{c}\text { Methylation Rate (\%) } \\
\text { of the Control Group }\end{array}$ & $\begin{array}{c}\text { Methylation Rate (\%) } \\
\text { of the Study Group }\end{array}$ \\
\hline PMS2 & 4.60 & 65.71 \\
\hline MSH6 & 12.40 & 67.14 \\
\hline MLH1 & 4.20 & 97.14 \\
\hline MSH2 & 12.00 & 24.28 \\
\hline MGMT & 8.50 & 82.85 \\
\hline MSH3 & 25.50 & 78.57 \\
\hline MLH3 & 1.10 & 75.71 \\
\hline
\end{tabular}

MLPA probe obtained on the undigested [-] sample. Multiplying this value with 100 gives an estimation of the percentage of methylation. Aberrant methylation can be identified by the appearance of a signal peak after $H$ haI digestion that was absent in the digested [ +$]$ reference DNA. Rates of methylation of all genes in a sample of each of the numerical values at the average

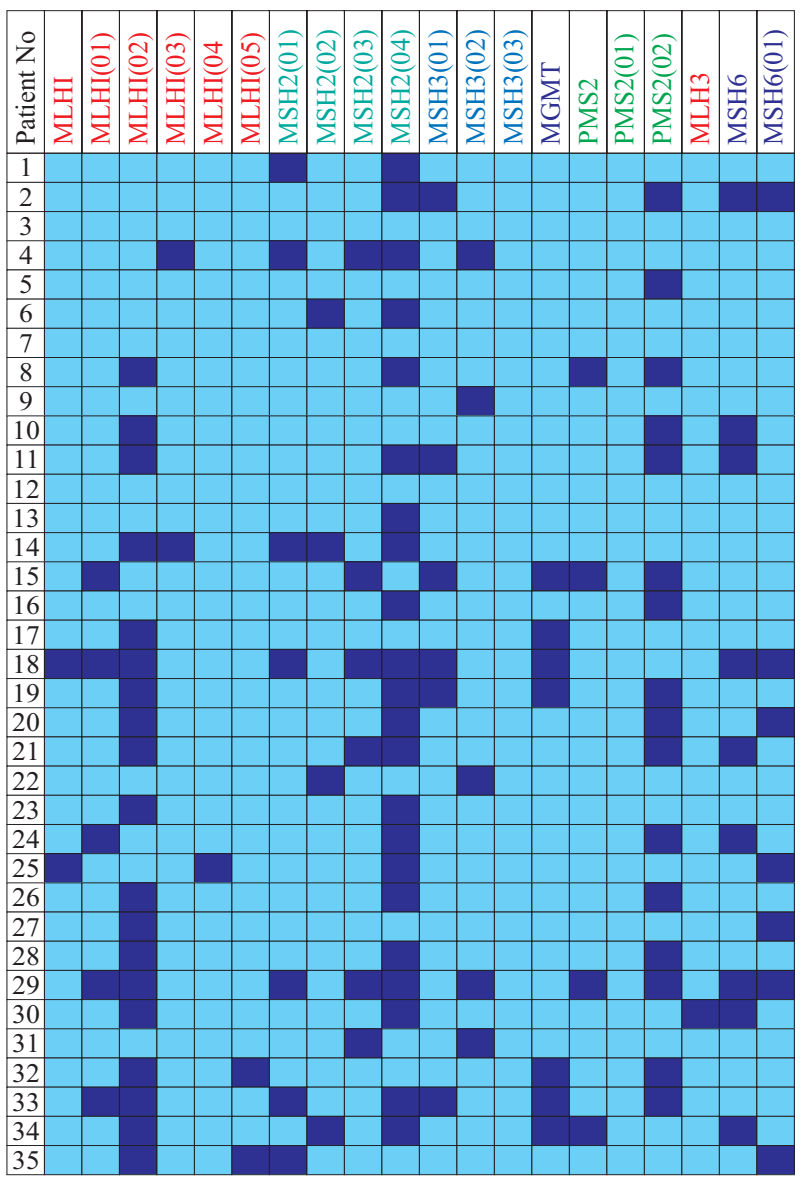

methylation percentages were compared to controls and study groups in Table 1. This after comparison with a high rate of methylation in genes in the study groups where there was methylation, as is shown in the methylation $[+]$ and non methylation $[-]$, marked in Supplementary tables S1 and S2, and Figures 1 and 2.

The MMR genes methylation ratio was determined in the pathological findings in all cases of subjects with colon cancer in our study (Table S2). According to the results of our study, the highest rate of methylation was in the MLH1 gene 68/70 (97.14\%) gene, and the rate was not so high in the MSH2 17/70 (24.28\%) gene.

Comparison of the diagnosis is given by gender, age groups and clinopathological characteristics in Tables 2, 3 and 4 . Therefore, patients with adenocarcinomas $(56.1 \%)$ and adenomas $(43.9 \%)$ were male, while patients with adenocarcinomas (89.7) and adenomas $(10.3 \%)$ were females; the difference between the two groups was statistically significant $\left(\chi^{2}=9.10, p=\right.$ $0.003<0.05$ ). Those patients under 60 years of age with adenocarcinomas (60.5\%) and adenomas (39.5\%), and

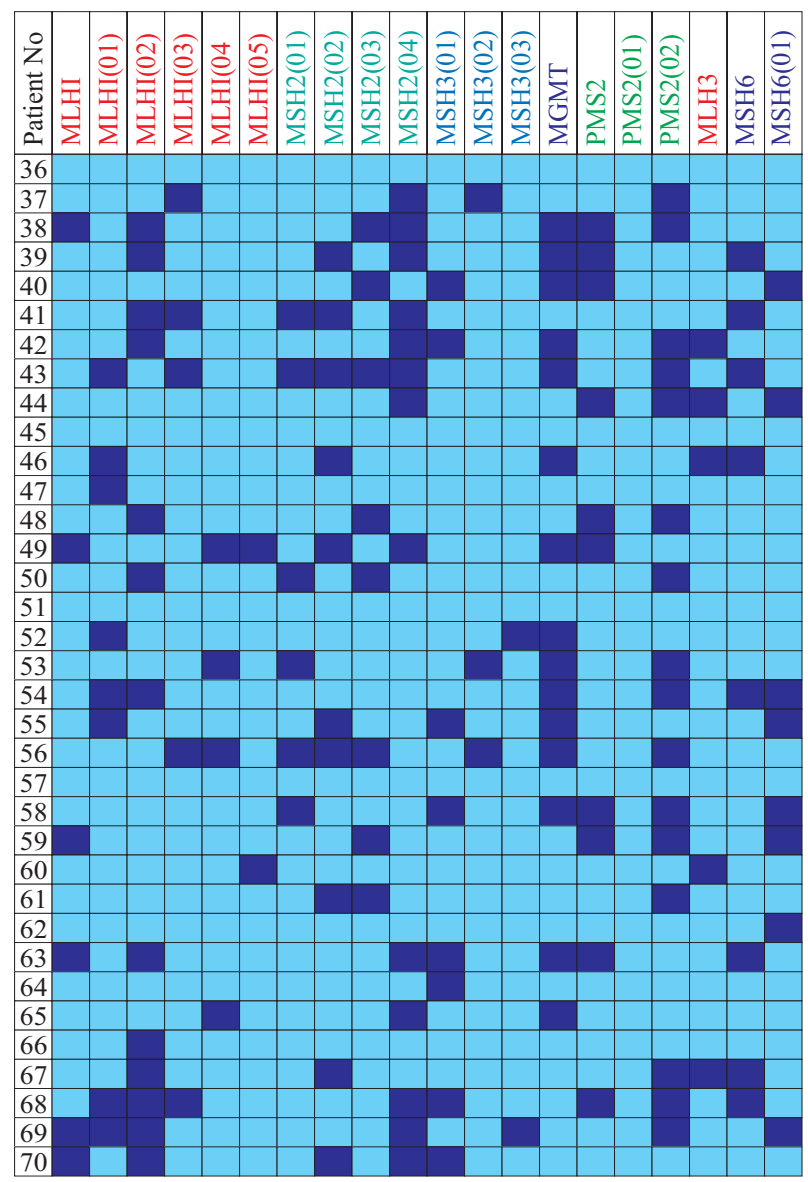

Figure 2. Promoter methylation of MMR genes. 
Table 3. The diagnosis percentages according to gender and age groups of clinopathological characteristics

\begin{tabular}{|c|c|c|c|c|c|c|c|}
\hline \multirow{3}{*}{ Genes } & & \multicolumn{4}{|c|}{ Diagnosis } & & \\
\hline & & \multicolumn{2}{|c|}{ Adenocarcinoma } & \multicolumn{2}{|c|}{ Adenoma } & \multicolumn{2}{|c|}{ Total } \\
\hline & & $n$ & $\%$ & $n$ & $\%$ & $n$ & $\%$ \\
\hline \multirow[t]{4}{*}{ Gender } & Males & 23 & 56.1 & 18 & 43.9 & 41 & 100.0 \\
\hline & Females & 26 & 89.7 & 3 & 10.3 & 29 & 100.0 \\
\hline & Total & 49 & 70.0 & 21 & 30.0 & 70 & 100.0 \\
\hline & & \multicolumn{2}{|c|}{$\chi 2=9.10 ; p=0.003<0.05$} & & & & \\
\hline \multirow[t]{4}{*}{ Age groups } & $<60$ & 23 & 60.5 & 15 & 39.5 & 38 & 100.0 \\
\hline & $>60$ & 26 & 81.3 & 6 & 18.8 & 32 & 100.0 \\
\hline & Total & 49 & 70.0 & 21 & 30.0 & 70 & 100.0 \\
\hline & & \multicolumn{2}{|c|}{$\chi^{2}=3.55 ; p=0.059>0.05$} & & & & \\
\hline
\end{tabular}

over 60 years of age with adenocarcinomas $(81.3 \%)$ and adenomas $(18.8 \%)(\chi 2=3.55, p=0.059>0.05)$. We obtained the following methylation rates: MLH1 (97.14\%), MGMT (82.85\%), MSH3 (78.57\%), MLH3 (75.71\%),
MSH6 (67.14\%), PMS2 (65.71\%), MSH2 (24.28\%).

The methylation percentage distribution by sex is given in Table 5. There was no difference observed between methylation for all genes and the percentages

Table 4. Diagnosis according to the percentages of methylation.

\begin{tabular}{|c|c|c|c|c|c|c|c|}
\hline \multirow{3}{*}{ Genes } & & \multicolumn{4}{|c|}{ Diagnosis } & & \\
\hline & & \multicolumn{2}{|c|}{ Adenocarcinoma } & \multicolumn{2}{|c|}{ Adenoma } & \multicolumn{2}{|c|}{ Total } \\
\hline & & $n$ & $\%$ & $n$ & $\%$ & $n$ & $\%$ \\
\hline \multirow[t]{3}{*}{ PMS2 } & High & 31 & 63.3 & 15 & 71.4 & 46 & 65.7 \\
\hline & Normal & 18 & 36.7 & 6 & 28.6 & 24 & 34.3 \\
\hline & & \multicolumn{2}{|c|}{$\chi 2=0.44 ; p=0.510>0.05$} & & & & \\
\hline \multirow[t]{3}{*}{ MSH6 } & High & 32 & 65.3 & 15 & 71.4 & 37 & 67.1 \\
\hline & Normal & 17 & 34.7 & 6 & 28.6 & 23 & 32.9 \\
\hline & & \multicolumn{2}{|c|}{$\chi^{2}=0.45 ; p=0.617>0.05$} & & & & \\
\hline \multirow[t]{3}{*}{ MLH1 } & High & 44 & 89.8 & 18 & 85.7 & 62 & 88.6 \\
\hline & Normal & 5 & 10.2 & 3 & 14.3 & 8 & 11.4 \\
\hline & & \multicolumn{2}{|c|}{$\chi 2=0.24 ; p=0.623>0.05$} & & & & \\
\hline \multirow[t]{3}{*}{$\mathrm{MSH} 2$} & High & 11 & 22.4 & 6 & 28.6 & 17 & 24.3 \\
\hline & Normal & 38 & 77.6 & 15 & 71.4 & 53 & 75.5 \\
\hline & & \multicolumn{2}{|c|}{$\chi^{2}=0.24 ; p=0.623>0.05$} & & & & \\
\hline \multirow[t]{3}{*}{ MGMT } & High & 41 & 83.7 & 17 & 81.0 & 58 & 82.9 \\
\hline & Normal & 8 & 16.3 & 4 & 19.0 & 12 & 17.1 \\
\hline & & \multicolumn{2}{|c|}{$\chi 2=0.08 ; p=0.782>0.05$} & & & & \\
\hline \multirow[t]{3}{*}{ MSH3 } & High & 40 & 81.6 & 15 & 71.4 & 55 & 78.6 \\
\hline & Normal & 9 & 1.4 & 6 & 28.6 & 15 & 21.4 \\
\hline & & \multicolumn{2}{|c|}{$\chi 2=0.91 ; p=0.340>0.05$} & & & & \\
\hline \multirow[t]{3}{*}{ MLH3 } & High & 36 & 73.5 & 17 & 81.0 & 53 & 75.7 \\
\hline & Normal & 13 & 26.5 & 4 & 19 & 17 & 24.3 \\
\hline & & \multicolumn{2}{|c|}{$\chi 2=0.45 ; p=0.503>0.05$} & & & & \\
\hline
\end{tabular}


Table 5. Percentages of methylation according to gender.

\begin{tabular}{|c|c|c|c|c|c|c|c|}
\hline \multirow[t]{2}{*}{ Genes } & & \multicolumn{2}{|c|}{ Males } & \multicolumn{2}{|c|}{ Females } & \multicolumn{2}{|c|}{ Total } \\
\hline & & $n$ & $\%$ & $n$ & $\%$ & $n$ & $\%$ \\
\hline \multirow[t]{3}{*}{ PMS2 } & High & 28 & 68.3 & 18 & 62.1 & 46 & 65.7 \\
\hline & Normal & 13 & 31.7 & 11 & 37.9 & 24 & 34.3 \\
\hline & & \multicolumn{2}{|c|}{$\chi^{2}=0.29 ; p=0.589>0.05$} & & & & \\
\hline \multirow[t]{3}{*}{ MSH6 } & High & 25 & 61.0 & 22 & 75.9 & 47 & 67.1 \\
\hline & Normal & 16 & 39.0 & 7 & 24.1 & 23 & 32.9 \\
\hline & & \multicolumn{2}{|c|}{$\chi 21.71 ; p=0.191>0.05$} & & & & \\
\hline \multirow[t]{3}{*}{ MLH1 } & High & 37 & 90.2 & 25 & 86.2 & 62 & 88.6 \\
\hline & Normal & 4 & 9.8 & 4 & 13.8 & 8 & 11.4 \\
\hline & & \multicolumn{2}{|c|}{$\chi^{2}=0.27 ; p=0.601>0.05$} & & & & \\
\hline \multirow[t]{3}{*}{ MSH2 } & High & 9 & 22.0 & & 27.6 & 17 & 24.3 \\
\hline & Normal & 32 & 78.0 & 21 & 72.4 & 53 & 75.7 \\
\hline & & \multicolumn{2}{|c|}{$\chi^{2}=0.29 ; p=0.588>0.05$} & & & & \\
\hline \multirow[t]{3}{*}{ MGMT } & High & 33 & 80.5 & 25 & 86.2 & 58 & 82.9 \\
\hline & Normal & 8 & 19.5 & 4 & 13.8 & 12 & 17.1 \\
\hline & & \multicolumn{2}{|c|}{$\chi^{2}=0.39 ; p=0.532>0.0$} & & & & \\
\hline \multirow[t]{3}{*}{ MSH3 } & High & 30 & 73.2 & 25 & 86.2 & 55 & 78.6 \\
\hline & Normal & 11 & 26.8 & 4 & 13.8 & 15 & 21.4 \\
\hline & & \multicolumn{2}{|c|}{$\chi^{2}=1.17 ; p=0.190>0.05$} & & & & \\
\hline \multirow[t]{4}{*}{ MLH3 } & High & 29 & 70.7 & 24 & 82.8 & 53 & 75.7 \\
\hline & Normal & 12 & 29.3 & 5 & 17.2 & 17 & 24.3 \\
\hline & Total & 41 & 100. & 29 & 100.0 & 70 & 100.0 \\
\hline & & \multicolumn{2}{|c|}{$\chi^{2}=1.34 ; p=0.284>0.05$} & & & & \\
\hline
\end{tabular}

of the gender groups $(p>0.05)$. The high percentage of methylation for PMS2 was $68.3 \%$ in males and $62.1 \%$ for females. The percentage rate for MSH6 was $61.0 \%$ for males and $75.9 \%$ for females; MLH1 percentage rate was $90.2 \%$ for males and $86.2 \%$ for females; MSH2 percentage rate was $22.0 \%$ in males and $27.6 \%$ for females; MGMT percentage rate was $80.5 \%$ for males and $86.2 \%$ females; MSH3 percentage rate was $73.2 \%$ for males and $86.2 \%$ for females, and the MLH3 percentage rate was $70.7 \%$ for males and $82.8 \%$ for females.

\section{DISCUSSION}

The MS-MLPA method for the analysis of the genes study, the tumor tissues isolated from patients with colon cancer genomic DNA. The MMR genes (PMS2, MSH6, MLH1, MSH2, MGMT, MSH3, MLH3) in terms of percentage of methylation and the frequency of methylation in a test of specific molecu- lar investigated by MS-MLPA management. The data obtained was presented according to the criteria evaluated for sex, age and type of case.

According to the relative proportions of defective MMR genes, MLH1, MSH2 and MSH6 are "major" and the remaining MMR genes are "minor" susceptibility genes. MLH1 and MSH2 account for nearly 90\% of all mutations, whereas MHS6 mutations occur in 7\% of HNPCC families, and the remaining genes are together responsible for under 5\% of HNPCC families. In Finland, the MLH1 accounts for more than $90 \%$ of Finnish HNPCC families with a known predisposing mutation [24]. This may be explained by the predominance of two common founding mutations of MLH1 (a 3.5k b genomic deletion of exon 16 and a splice acceptor site mutation of exon 6 ), which account for $63 \%$ of all mutations detected in Finnish HNPCC kindreds [25,26].

In general, MMR gene mutations are spread equally over the coding sequences of the three major susceptibility genes and their exon-intron boundar- 
ies. Of these, five mutation hot-spots were detected in MLH1 exons 1 and 16, MSH2 exons 3 and 12, and MSH6 exon 4 [12]. The majority (81\%) of inherited MLH3 mutations are clustered in exon 1 [27]. Most MLH1 and MSH2 mutations are nonsense (11 and 49\%) and frameshift mutations (44 and 19\%) that cause the truncation and loss-of-function of the respective protein product. Missense mutations account for $32 \%$ of MLH1 and $18 \%$ of MSH6 mutations. Often, these mutations, especially missense mutations of MSH6, are associated with small or atypical HNPCC families, sometimes with milder phenotypes, thus their pathogenicity is more difficult to determine [28,29]. Due to the rarity of mutations in the remaining genes, the analysis of mutation distribution and frequency of different types of mutations remains unknown. We have considered adenoma and adenocarcinoma in patients with colon cancer in two different groups.

A nearly $61.63 \%$ rate of methylation of MMR genes is seen to occur in patients with adenocarcinomas and $49.91 \%$ in patients with adenomas. Epigenetics provide a new perspective for the early diagnosis, treatment and prognosis of these tumors. Studies indicate that $\mathrm{CpG}$ island methylation in the MMR genes are also a mechanism underlying gene inactivation and tumorigenesis [30,31]. With the development of epigenetics in recent years, DNA methylation has gradually become a new research focus. In the human genome, 5' promoters of $50 \%$ of genes contain a $\mathrm{CpG}$ region, also known as a CpG island, with a length of $>197 \mathrm{bp}$. The $\mathrm{CpG}$ island is in a non methylation state under normal circumstances. The $\mathrm{CpG}$ island methylation may lead to the loss of gene expression and replication errors $[32,33]$. The promoter methylation of the hMLH1 gene is the most common in known MMRs genes. The detection rate of the hMLH1 gene promoter methylation in our study was very similar to the reported data [34].

Increasing knowledge on the properties of the MMR system and its connections to other biological pathways is essential to better understand the fundamental mechanisms of cancer development and to identify targets for preventive and therapeutic interventions. We think our analyses revealed novel and non random epigenetic patterns that contribute to the understanding of the developmental mechanisms of colon cancers, which is in agreement with what has been previously reported by others [1].

\section{ACKNOWLEDGMENTS}

The study was supported by grants from the Science Faculty of Afyon Kocatepe University Research Project Commission and the project number is 07.FENED.12.

\section{REFERENCES}

1. Peltomäki P. Role of DNA mismatch repair defects in the pathogenesis of human cancer. J Clin Oncol. 2003; 21(6): 1174-1179.

2. Chan TL, Yuen ST, Ho JW, Chan AS, Kwan K, Chung LP, Lam PW, Tse CW, Leung SY. A novel germline 1.8$\mathrm{kb}$ deletion of hMLH1 mimicking alternative splicing: a founder mutation in the Chinese population. Oncogene. 2001; 20(23): 2976-2981.

3. Li L, McVety S, Younan R, Liang P, Du Sart D, Gordon PH, Hutter P, Hogervorst FB, Chong G, Foulkes WD. Distinct patterns of germline deletions in MLH1 and MSH2: the implication of Alu repetitive element in the genetic etiology of Lynch syndrome (HNPCC). Hum Mutat. 2006; 27(4): 388.

4. Jeuken JW, Cornelissen JBS, Vriezen M, Dekkers MMG, Errami A, Sijben A, Boots-Sprenger SHE, Wesseling P. MS-MLPA: an attractive alternative laboratory assay for robust, reliable, and semiquantitative detection of MGMT promoter hypermethylation in gliomas. Lab Invest. 2007; 87(10): 1055-1065.

5. Kunkel TA, Erie DA. DNA mismatch repair. Annu Rev Biochem. 2005; 74: 681-710.

6. Strand M, Prolla TA, Liskay RM, Petes TD. Destabilization of tracts of simple repetitive DNA in yeast by mutations affecting DNA mismatch repair. Nature. 1993; 365(6443): 274-276.

7. Sia EA, Kokoska RJ, Dominska M, Greenwell P, Petes TD. Microsatellite instability in yeast:dependence on repeat unit size and DNA mismatch repair genes. Mol Cell Biol. 1997; 17(5): 2851-2858.

8. Peltomäki P, Aaltonen LA, Sistonen P, Pylkkanen L, Mecklin JP, Järvinen H, Green JS, Jass JR, Weber JL, Leach FS, Petersen GM, Hamilton SR, de la Chapelle A, Vogelstein B. Genetic mapping of a locus predisposing to human colorectal cancer. Science. 1993; 260(5109): 810-812.

9. Peltomäki P. Lynch syndrome genes. Fam Cancer. 2005; 4(3): 227-232.

10. Liu T, Yan H, Kuismanen S, Percesepe A, Bisgaard ML, Pedroni M, Benatti P, Kinzler KW, Vogelstein B, Ponz de Leon M, Peltomäki P, Lindblom A. The role of hPMS1 and hPMS2 in predisposing to colorectal cancer. Cancer Res. 2001; 61(21):7798-7802.

11. Huang J, Kuismanen SA, Liu T, Chadwick RB, Johnson CK, Stevens MW, Richards SK, Meek JE, Gao X, Wright FA, Mecklin J-P, Järvinen HJ, Grönberg H, Bisgaard 
ML, Lindblom A, Peltomäki P.MSH6 and MSH3 are rarely involved in genetic predisposition to nonpolypotic colon cancer. Cancer Res. 2001; 61(4): 1619-1623.

12. Peltomäki P, Vasen H. Mutations associated with HNPCC predisposition - Update of ICGHNPCC/INSiGHT mutation database. Dis Markers. 2004; 20(4-5): 269-276.

13. Tannergård P, Lipfordd JR, Kolodner R, Frodin RJE, Nordenskjöld M, Lindblom A. Mutation screening in the hMLH1 gene in Swedish hereditary nonpolyposis colon cancer families. Cancer Res. 1995; 55(24): 6092-6096.

14. Vasen. HFA., Wijnen J, Menko FH, Kleibeuker JH, Taal BG, Griffioen G, Nagengast FM, Meijers-Heijboer EJ, Bertario L, Varesco L, Bisgaard M, Mohr J, Fodde R, Meera Khan P. Cancer risk in families with hereditary nonpolyposis colorectal cancer diagnosed by mutation analysis. Gastroenterology. 1996; 110(4): 1020-1027.

15. Kane MF, Loda M, Gaida GM, Lipman J, Mishra R, Goldman H, Jessup JM, Kolodner, R. Methylation of the hMLH1 promoter correlates with lack of expression oh hMLH1 in sporadic colon tumors and mismatch repair-defective human tumor cell lines. Cancer Res. 1997; 57(5): 808-811.

16. Herman JG, Umar A, Plyak K, Graff JR, Ahuja N, Issa J-PJ, Markowitz S, Willson JKV, Hamilton SR, Kinzler KW, Kane MF, Kolodner RD, Vogelstein B, Kunkel $\mathrm{TA}$, Baylin SB. Incidence and functional consequences of hMLH1 promoter hypermethylation in colorectal carsinoma. Proc Natl Acad Sci USA 1998; 95(12): 6870-6875.

17. Gisselsson D. Chromosome instability in cancer: how, when, and why? Adv Cancer Res. 2003; 87: 1-29.

18. Esteller M, Herman JG. Cancer as an epigenetic disease: DNA methylation and chromatin alterations in human tumours. J Pathol. 2002; 196(1): 1-7.

19. Esteller M. Relevance of DNA methylation in the management of cancer. Lancet Oncol. 2003; 4(6): 351-358.

20. Schouten JP, McElgunn CJ, Waaijer R, Zwijnenburg D, Diepvens F, Pals G. Relative quantification of 40 nucleic acid sequences by multiplex ligation-dependent probe amplification. Nucleic Acids Res. 2002; 30(12): e57.

21. MRC-Holland, Amsterdam, The Netherlands. http:// www.mrcholland. com. Cited 16 Feb 2009.

22. Jeuken JWM, Cornelissen S, Boots-Sprenger SHE, Gijsen S, Wesseling P. Multiplex ligation-dependent probe amplification (MLPA): a diagnostic tool for simultaneous identification of different genetic markers in glial tumors. J Mol Diagnostics. 2006; 8(4): 433-443.

23. Morak M, Schackert HK, Rahner N, Betz B, Ebert M, Walldorf C, Royer-Pokora B, Schulmann K, von Knebel-Doeberitz M, Dietmaier W, Keller G, Kerker B. Fur- ther evidence for heritability of an epimutation in one of 12 cases with MLH1 promoter methylation in blood cells clinically displaying HNPCC. Eur J Hum Genet. 2008; 16(7): 804-811.

24. Nyström-Lahti M, Wu Y, Moisio A-L, Hoftra RMW, Osinga J, Mecklin J-P, Järvinen HJ, Leisti J, Buys CHCM, de la Chapelle A, Peltomäki P. DNA mismatch repair gene mutations in 55 kindreds with verified or putative hereditary non-polyposis colorectal cancer. Hum Mol Genet. 1996; 5(6): 763-769.

25. Nyström-Lahti M, Kristo P, Nicolaides NC, Chang SY, Aaltonen LA, Moisio AL, Järvinen HJ, Mecklin JP, Kinzler KW, Vogelstein B, de la Chapelle A, Peltomäki P. Founding mutations and Alu mediated recombination in hereditary colon cancer. Nat Med. 1995; 1(11): 12031206.

26. Moisio AL, Sistonen P, Weissenbach J, de la Chapelle A, Peltomäki P. Age and origin of two common MLH1 mutations predisposing to hereditary colon cancer. Am J Hum Genet. 1996; 59(6): 1243-1251.

27. Liu HX, Zhou XL, Liu T, Werelius B, Lindmark G, Dahl $\mathrm{N}$, Lindblom A. The role of hMLH3 in familial colorectal cancer. Cancer Res. 2003; 63(8): 1894-1899.

28. Kariola R, Raevaara TE, Lonnqvist KE, Nyström-Lahti M. Functional analysis of MSH6 mutations linked to kindreds with putative hereditary non-polyposis colorectal cancer syndrome. Hum Mol Genet. 2002; 11(11): 1303-1310.

29. Kariola R, Hampel H, Frankel WL, Raevaara TE, de la Chapelle A, Nyström-Lahti M. MSH6 missense mutations are often associated with no or low cancer susceptibility. Br J Cancer. 2004; 91(7): 1287-1292.

30. Deng G, Peng E, Gum J, Terdiman J, Sleisenger M, Kim YS. Methylation of hMLH1 promoter correlates with the gene silencing with a region-specific manner in colorectal cancer. Br J Cancer. 2002; 86(4): 574-579.

31. Boland CR, Goel A. The silence of the genes: matching mismatch repair defects with tumors. Cancer. 2003; 98(1): 2091-2094.

32. Jubb AM, Bell SM, Quirke P. Mythylation and colorectal cancer. J Pathol. 2001; 195(1): 111-134.

33. Deng G, Chen A, Hong J, Chae HS, Kim YS. Methylation of $\mathrm{CpG}$ in a small region of the hMLH1 promoter invariably correlates with the absence of gene expression. Cancer Res. 1999; 59(9): 2029-2033.

34. Hawkins N, Norrie M, Cheong K, Mokany E, Ku SL, Meagher A, O'Connor T, Ward R. CpG island methylation in sporadic colorectal cancers and its relationship to microsatellite instability. Gastroenterology. 2002; 122(5): 1376-1387. 
